de de Filosofia, Letras e Ciências Humanas da USP para a concessão de um espaco, a APLL utiliza como sede a sala 167-A do Prédio de Letras daquela Faculdade. Ali, a bolsista do referido Programa Bolsa-Trabalho da COSEAS desenvolve atividades de atendimento ao público, de divulgação da APLL, de organização de arquivos, de correspondência, etc. Envolveu-se, portanto, efetivamente, a universidade com a APLL.

O ponto mais importante dessa discussão, no entanto, reside na questão de, por um lado, verificar que esse envolvimento da USP com as atividades da APLL tem permitido que a Associação alcance seus propósitos. Por outro, é fundamental insistir na configuração da APLL como entidade independente, autônoma, capaz de auto-gerir-se; isso não exclui o uso e o apoio de uma instituição que, afinal, pertence à sociedade. É necessário, assim, manter o espaço conquistado e a infraestrutura que aquela instituição pode oferecer para a implementação dos novos rumos para o ensino de primciro e segundo graus, pretendidos pela APLL, pelas secretarias de educação e pela sociedade em geral.
Artigo

\section{DIÁLOGOS INTERTEXTUAIS NO ENSINO DE LÍNGUA PORTUGUESA*}

Norma Seltzer Goldstein**

Resumo: $O$ artigo apresenta uma proposta didática de trabalho com textos verbais (literários e não literários) e não verbais (histórias em quadrinhos), a fim de que os professores de $1^{\circ} \mathrm{e} 2^{\circ} \mathrm{Graus}$ possam refletir sobre essa estratégia em suas aulas de lingua materna ou em atividades interdisciplinares.

Palavras-chave: Texto, Contexto, Efeito de sentido

\section{Considerações preliminares}

Na realidade da sala de aula, o ensino deve ocorrer de forma contextualizada. Assim sendo, o trabalho com o texto se insere num conjunto de atividades, desenvolvidas em função de uma programação que leva em conta a situação da escola e da comunidade, bem como o nível e o interesse dos alunos. Nesse sentido, minhas sugestões devem ser vistas como um recorte, com finalidade didática. É preciso ter clareza de que, em sala de aula, seria necessário fazer uma contextualização que ampliasse e complementasse estas atividades centradas no diálogo entre textos com temática comum, visando a uma reflexão sobre o modo como se poderia levar o aluno a apreciar, compreender, analisar e interpretar textos. Numa etapa seguinte, fica implícito que deveria haver todo um trabalho complementar.

O paralelo entre textos é uma estratégia que torna evidentes não só as semeIhanças, mas também as diferenças, tanto no aspecto formal, como no temático e no ideológico, já que cada texto se embasa num ponto de vista especifico. Gostaria

* Este texto retoma, com modificações, parte do mini-curso $A$ Leitura como Construção do Texto $e$ Construção do Real, ministrado no Seminário Nacional de Literatura Infantil e Juvenil, no àmbito da 14" Bienal do Livro, em agosto de 1996.

** Professora de Língua Portuguesa na USP, autora, entre outros, de Roteiro de Leitura do Romanceiro da Inconfidência, Ed. Atica, 1997; e da coleção didática Linguagem e Vida (54 a 8* s.), Ed. Ática, 1993. 
de apontar o caminho do "diálogo" textual, como uma das estratégias didáticas para o trabalho em sala de aula, voltada para duas direções:

1. a primeira consiste em ler um texto (ou mais de um) que retoma outro, anterior, segundo uma nova perspectiva;

2. a segunda tem como eixo a comparação de dois ou mais textos diversos sobre o mesmo tema, visando a confrontar semelhanças e divergências.

\section{Extenpasuagucs}

\subsection{Retomada de um texto por outro}

Em um poema do livro Os Bichos (Ed. Ática), José Paulo Paes revê uma fábula clássica:

Sem barra

Enquanto a formiga

carrega a comida

para o formigueiro,

a cigarra canta,

$s$

canta o dia inteiro.

A formiga é só trabalho.

A cigarra é só cantiga

Mas sem à cantiga

da cigarra

10.

que distrai da fadiga,

seria uma barra

o trabalho da formiga.

Fica evidente o paralelo com a fábula $A$ cigarra e a formiga, de La Fontaine, na qual o trabalho da formiga é premiado com abrigo e alimento, enquanto a cantoria da cigarra é castigada com o desabrigo e o risco de vida. A retomada aparece na estrofe inicial.

No dístico central, o verbo de ligação ( "é") aponta a imagem cristalizada no imaginário coletivo pela tradição: a formiga, identificada ao trabalho; e a cigarra, ao canto. No entanto, nessa mesma estrofe, as rimas apontam em direção contrária: "cigArra" faz rịma toante com trabAlho, enquanto formIGA apresenta rima consoante com cantIGA. Ou seja, a imagem estratificada pelo verbo de ligação que retoma a visão conservadora da fábula aparece em tensão com a sugestão sonora, já que a rima aponta para a ruptura com o modelo tradicional.

A estrofe final abre com um "mas", anunciador de oposição. O ponto de vista contemporâneo diverge do clássico : canto $e$ trabalho não são excludentes, mas complementares: ... sem a cantiga, seria uma barra o trabalho da formiga.

Caberia uma discussão com os leitores, sobre os sentidos - denotativo e conotativo- de trabalho e de canto: o trabalho é sempre desagradável? existe a possibilidade de se trabalhar no que se gosta? as pessoas só trabalham para seu próprio grupo, como a formiga? ou haveria a hipótese de o trabalho ter uma função social mais ampla? a cantiga pode ser associada a quê? a atitudes negativas como preguiça e vagabundagem? ou, de modo positivo, a dança, lazer, alegria, festa, descontração? trabalho e cantiga seriam necessariamente opostos e excludentes? a vida das pessoas deve ser voltada só para um tipo de atividade, como a da cigarra e da formiga da fábula? é possível se viver sem trabalho? qual a importância do lazer? etc.

As fábulas clássicas, além de textos literários, eram também um conjunto de exemplos moralistas e educativos, segundo a visão de mundo de certa classe em determinada época. La Fontaine - autor francês do século XVII- pretendia incutir nos jovens em formação a noção da importância do trabalho e dos riscos da "preguiça", defeito terrivel, verdadeira falha de caráter. A linguagem da fábula que também deveria ser lida em classe - é formal e bastante cuidada. José Paulo Paes diverge do texto com o qual dialoga, também nesse aspecto: o título e o antepenúltimo verso trazem uma expressão coloquial, "sem barra", que dá uma nota descontraida e bem humorada ao conjunto do poema, escrito em liguagem culta padrão, com presença de rimas e composição simétrica ( Estrofe 1: cinco versos; Estrofe 2: dois versos; Estrofe 3: cinco versos). O poema contemporâneo, por um lado, homenageia o clássico, ao recuperá-lo para o leitor de hoje; por outro, diverge dele, descartando a receita redutora de que haveria um $\mathrm{mc}$ delo único de comportamento a ser seguido. À diversidade de individuos e de temperamentos, tem de corresponder, necessariamente, a multiplicidade de opções para as atividades humanas.

O mesmo exercício se aplica à letra de uma canção de Chico Buarque de Hollanda:

\section{Bom Conselho}

Ouça um bom conselho

Que lhe dou de graça

Inútil dormir

Que a dor não passa 
$5 \quad$ Espere sentado

Ou você se cansa

Está provado

Quem espera nunca alcança

Ouça meu amigo

10

Deixe esse regaço

Brinque com meu fogo

Venha se queimar

Faça como eu digo

Faça como eu faço

15 Aja duas vezes antes de pensar.

Corro atrás do tempo

Vim de não sei onde

Devagar é que

Não se vai longe

20

Na minha cidade

Vou pra rua e bebo a tempestade.

O leitor percebe a releitura de provérbios que fazem parte do repertório de todo falante do português do Brasil, e que o autor desloca, poeticamente: $O$ sono é bom conselheiro (v. 3/4); Quem espera sempre alcança (v.5/6 e v. 8); Quem brinca com fogo pode se queimar ( v.11/12); Pense duas vezes antes de agir (v.15); devagar se vai longe (v.18/ 19); quem semeia ventos, colhe tempestades (v.20 a 22).

O pocma apresenta um questionamento das regras de comportamento, através de um recurso que gera duplicidade de sentido: ocorre, simultaneamente, a retomada da moral dos provérbios e a inversão de seu significado.

Surgcm várias qucstõcs a debatcr, começando pela ambigüidade do titulo: 0 que seria, realmente, um Bom conselho? e, ainda, qual o valor de algo dado de graça, no tipo de socicdade mercantilista em que vivemos? queimar-se no.fogo é sempre ruim? e se for o fogo amoroso? "colher tempestades" é uma experiência necessariamente negativa? por que o poeta semeia ventos para beber a tempestade? etc.

Ao reverter a moral padronizada da sabedoria popular, passada de geração a geração através dos provérbios, Chico Buarque imprime um tom irônico e contestador à letra de sua canção, nuın movimento de dupla direção: numa via, a busca da valorização da tradição; na outra, a proposta de releitura critica do legado cultural, segundo a perspectiva do presente.

\subsection{Três textos, um mesmo tema}

\section{I- O radar}

O radar emite ondas radielétricas que se refletem nos obstáculos que encontram e retornam a um receptor como um eco. As propriedades do eco são usadas para formar uma figura para determinar certas caracteristicas do objeto que provocou a reflexão. Há diferentes tipos de sistemas de radar, utilizando diferentes propriedades do eco recebido e diferentes tipos de radiotransmissão. (Enciclopédia Mirador Internacional, Enc. Brit. do Brasil, 1970).

II-
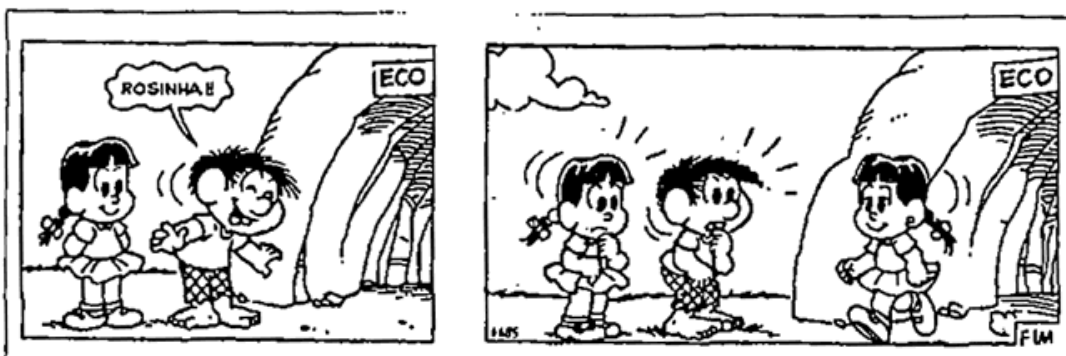

Maurício de Souza. Estadinho.

III-

\section{oeco}

O menino pergunta ao eco

Onde é que ele se esconde

Mas o eco só responde: "Onde? Onde?"

O menino também lhe pede:

5 "Eco, vem passear comigo!"

Mas não sabe se o eco é amigo

Ou inimigo

Pois só lhe ouve dizer:

"Migo!" 
O paralelo entre os três textos aponta o tema comum e permite perceber as diferenças.

Em I-, a definição informativa está organizada em linguagem simples, direta, de caráter explicativo, com um único sentido: o denotativo.

Em II-, a tira de Mauricio de Souza explora visualmente o recurso da repetição, num efeito humorístico. Ao grito de "Rosinha!", a expectativa do leitor seria a resposta sonora. Inesperadamente, surge o eco visual, causando tremor e espanto nas crianças, no segundo quadrinho: 1) Chico fica sem fala, como indica o balão em branco; 2) os riscos, em tomo das duas imagens infantis, sugere tremedeira; 3) aparece um ar de susto no rosto das crianças, substituindo o riso do quadrinho anterior. $O$ texto é narrativo, já que a sequiência de quadrinhos indica sucessão temporal; também tem aspectos descritivos, ao retratar personagens e sua reação.

Em III-, o poema de Cecilia Meireles personifica o eco, transformando-o em interlocutor virtual do menino que tenta dialogar com ele, mas fica sem resposta, já que ele só repete o final das frases que lhe são dirigidas. O jogo de sonoridades do texto explora as características repetitivas do eco, refletidas nas rimas: 1 ) esconde/ responde / oude/ onde ; 2) comigo / amigo / inimigo / migo. Através de uma ingênua brincadeira infantil, ao sentido denotativo acrescenta-se o conotativo, pois o poema lança a sugestão metafórica e rítmica de que o eco refletiria o relacionamento entre pessoas, num efeito de ida e volta, busca e retomo. Surge o paralelo com a própria vida, na qual nem sempre o retorno corresponde às expectativas de quem busca, sendo parcial ou ambíguo - como as respostas, no poema. Esse efeito seria impossivel, sem os recursos formais e sonoros, especificos da linguagem poética.

Num paralelo entre os três textos, ressalta a complexidade da linguagem literária (III), em relação à simplicidade da definição (I) e à relativa complexidade da história em quadrinhos (II). Há certo parentesco entre o poema e a tirinha. Apesar da diferença de linguagens, o efeito sobre o leitor é mais ou menos semelhante: o leitor lê, relê, (re)descobrindo sentidos. A distinção parece ser de intensidade. $\mathrm{O}$ poema tem maior carga poética, mais riqueza sugestiva, sua significação vai-se ampliando, a cada nova leitura. Num processo imitativo ao do eco, o leitor constrói incessantemente um novo sentido para o texto, refletindo-o numa reconstrução de sentido para a própria realidade.

\section{Proposta de reflexão}

Os exemplos acima devem ser entendidos como sugestões, ou melhor: como relatos de experiência, já que foram empregados em várias ocasiões em sala de aula. Gostaria que servissem de ponto de partida para uma reflexão dos professores sobre esse tipo de estratégia didática - contemplada, aliás, nas Propostas Curriculares $^{I}$ do Estado de São Paulo. Trata-se de recurso bastante operacional, cujos resultados podem ir além do ensino de Língua Portuguesa; já que, dependendo da situação escolar, 'é possivel realizar um trabalho interdisciplinar, recorrendo a paralelos com textos de outras áreas do conhecimento. Neste último caso, além da atividade com a disciplina propriamente dita, o professor estaria também trabathando a função instrumental da língua materna. $\mathrm{E}$ torno a insistir: como todas as outras atividades, esta tambèm deve ser contextualizada.

Abstract: This article gives suggestions of work with different kinds of texts - literary and others such as cartoons - to provide to teachers of Portuguese as a mother tongue the opportunity of reflection about it.

Key-words: Text, Context
1 Proposta Curricular de Lingua Portuguesa para o $1^{\circ}$ grau e Proposta Curricular de Lingua Portuguesa para o ensino de $2^{\circ}$ grau, CENP SE ESP, 1991. 